\title{
Phospholipase $C-\beta_{1}$ is regulated by a pertussis toxin-insensitive $\mathbf{G}$-protein
}

\author{
Thomas F. J. MARTIN, ${ }^{*}$ Janet E. LEWIS and Judith A. KOWALCHYK \\ Department of Zoology, University of Wisconsin, Madison, WI 53706, U.S.A.
}

\begin{abstract}
Regulation of phospholipase C (PLC) by receptors is mediated either through protein tyrosine phosphorylation or by activation of GTP-binding proteins $\left(\mathrm{G}_{\mathrm{p}}\right)$. For the latter, pertussis toxin (PT)-sensitive and -insensitive pathways have been described, indicating PLC regulation by at least two types of G-proteins. The identity of PLC isoenzymes which are regulated by either type of $G_{p}$ remains to be determined. Thyrotropin-releasing hormone stimulates a PLC in $\mathrm{GH}_{3}$ cells via a PT-insensitive $G_{p}$. Reconstitution methods for the assay of the $\mathrm{GH}_{3}$-cell $G_{p}$ were developed. Previously, the membrane PLC was found to be reversibly extracted from membranes by high salt and to be activated by guanosine $5^{\prime}$ [ $\gamma$-thio]triphosphate (GTP[S]) only when membrane-associated, suggesting that $G_{p}$ was retained in salt-extracted membranes. In the present work, $G_{p}$ was cholate-solubilized from PLC-deficient membranes and incorporated into phospholipid vesicles, which were found to confer GTP[S]- and $\mathrm{AlF}_{4}{ }^{-}$-stimulated activity on a solubilized membrane PLC. The reconstitution provided a direct assay for the $\mathrm{GH}_{3}$-cell $G_{p}$ which was shown to be distinct from $G_{i}, G_{0}$ and $G_{s}$ proteins by immunodepletion studies. Incorporation of G-protein $\beta-\gamma$ subunits into phospholipid vesicles with $G_{p}$ inhibited GTP[S]-stimulated activity in the reconstitution. The results indicated that $G_{p}$ is a heterotrimeric G-protein with the properties expected for the PT-insensitive $\mathrm{GH}_{3}$-cell $\mathrm{G}_{\mathrm{p}}$ protein. PLC- $\beta_{1}$ was fully purified and shown to be regulated by $\mathrm{G}_{\mathrm{p}}$ in the reconstitution. In contrast, PT-sensitive G-proteins failed to affect the activity of PLC- $\beta_{1}$. The results indicate (1) that a PT-insensitive $G_{p}$ regulates PLC- $\beta_{1}$ and (2) that PT-sensitive and -insensitive pathways of PLC regulation employ different PLC isoenzymes as well as different G-proteins.
\end{abstract}

\section{INTRODUCTION}

Two mechanisms have been identified by which hormone and growth-factor receptors regulate phosphoinositide hydrolysis. One of these involves growth-factor-receptor protein tryosine kinase-mediated phosphorylation of phospholipase C (PLC)- $\gamma$ $[1,2]$. The other mechanism is similar to that of receptor-regulated adenylate cyclase or photon-activated cyclic GMP phosphodiesterase and involves GTP-binding (G) proteins [2-5]. Hormone activation of phosphoinositide hydrolysis in membranes is potentiated by GTP and mimicked by hydrolysis-resistant GTP analogues [2-9]. Results of studies employing bacterial toxin ADP-ribosyltransferases to evaluate G-protein involvement suggest that several different G-proteins $\left(\mathrm{G}_{\mathrm{p}} \mathrm{s}\right)$ mediate receptor regulation of PLC. Agonist-specific and tissue-specific PLC regulation has been reported to be inhibited by either pertussis toxin (PT) $[2,3]$ or cholera toxin $(\mathrm{CT})[2,10]$, or to be unaffected by either toxin $[2,4,7,9]$. For PT-sensitive systems, PLC regulation appears to involve $G_{1}$ and/or $G_{0}$ [11-15]. PT-insensitive Gproteins that regulate PLC activity have recently been described $[16,17]$.

The study of $\mathrm{G}_{\mathrm{p}}$ regulation of PLC activity would be facilitated by the development of functional reconstitution methods analogous to those used for the study of the regulation of adenylate cyclase [18]. Several cytosolic and membrane PLCs have been purified and characterized $[2,19,20]$. Although studies have documented a role for PLC- $\gamma$ in growth-factor signal transduction [1], the role of other PLC isoenzymes remains to be established. Attempts to regulate the activity of purified PLCs with purified heterotrimeric $\mathrm{G}$ proteins have met with limited success $[17,19,20]$.
In the present paper, we describe a reconstitution assay for a membrane $G_{p}$ present in $\mathrm{GH}_{3}$ pituitary cells. Well-washed $\mathrm{GH}_{3}$ cell membranes exhibit PLC activity which is stimulated by thyrotropin-releasing hormone (plus GTP) or by nonhydrolysable GTP analogues [6,8]. The regulation of PLC activity by hormone (plus GTP) is PT-insensitive [7,21]. In a previous study [22], we found that the membrane PLC was solubilized by salt extraction and that the soluble enzyme lacked guanosine 5'[ $\gamma$-thio]triphosphate (GTP[S])-stimulated activity, suggesting that the PLC was separated from $G_{p}$. Incubation of the desalted membrane enzyme, or a similarly prepared brain membrane PLC, with extracted membranes resulted in the association of the PLC with the membrane and the reconstitution of GTP[S]stimulated activity. It was concluded that $G_{p}$ remained membrane-associated and was able to couple with the solubilized membrane PLC [22]. In the present study, $G_{p}$ was cholatesolubilized from PLC-deficient $\mathrm{GH}_{3}$-cell membranes, incorporated into phospholipid vesicles and shown to confer GTP[S]regulated activity on purified PLC- $\beta_{1}$. In contrast, PT-sensitive G-proteins failed to affect the activity of PLC- $\beta_{1}$. The results indicate that PT-sensitive and -insensitive pathways of PLC regulation employ distinct PLC isoenzymes as well as distinct heterotrimeric G-proteins.

\section{MATERIALS AND METHODS}

\section{PLC assay}

Assays were conducted at $37^{\circ} \mathrm{C}$ for 60 min (unless otherwise noted) in a total volume of $50 \mu \mathrm{l}$ containing $0.02 \mathrm{M}$-Tris, $\mathrm{pH} 7.0$, $0.1 \mathrm{M}-\mathrm{NaCl}, 2.5 \mathrm{mM}-\mathrm{MgCl}_{2}, 2 \mathrm{mM}$-EGTA, $\mathrm{CaCl}_{2}$ (added to provide $30 \mathrm{nM}$ free $\left.\mathrm{Ca}^{2+},[7]\right)$ and $\left[{ }^{3} \mathrm{H}\right] \mathrm{PtdIns} P_{2}$.

\footnotetext{
Abbreviations used: PLC, phospholipase C; NEtMal, $N$-ethylmaleimide; PtdEtn, phosphatidylethanolamine; PtdSer, phosphatidylserine; GTP[S], guanosine $5^{\prime}$-[ $\gamma$-thio]triphosphate; ATP[S], adenosine $5^{\prime}$-[ $\gamma$-thio]triphosphate; $\left[\right.$ [NH]ppG, guanosine $5^{\prime}$-[ $[\beta \gamma$-imido]triphosphate; GDP[S], guanosine $5^{\prime}$-[ $\beta$-thio]diphosphate; G-protein, GTP-binding protein; AMF, $10 \mu \mathrm{M}-\mathrm{AlCl}_{3} / 6 \mathrm{mM}-\mathrm{MgCl}_{2} / 10 \mathrm{mM}-\mathrm{NaF}$; PT, pertussis toxin; CT, cholera toxin.

* To whom correspondence should be addressed: Zoology Research Building, University of Wisconsin, 1117 W. Johnson Street, Madison, WI 53706, U.S.A.
} 
$\left[{ }^{3} \mathrm{H}\right] \mathrm{PtdIns} P_{2}$ substrate was prepared as previously described [22]; final concentrations of lipids in the assay were $100 \mu \mathrm{M}$ PtdIns $P_{2} \quad\left(2 \times 10^{4}\right.$ d.p.m./tube $), \quad 400 \mu$ M-phosphatidylethanolamine (PtdEtn), $400 \mu \mathrm{M}$-phosphatidylserine (PtdSer) and $\sim 0.5$ mM-sodium cholate. $\operatorname{Ptd}\left[2-{ }^{3} \mathrm{H}\right] \operatorname{Ins}(4,5) P_{2}$ was purchased from DuPont-New England Nuclear, and other lipids were from Sigma Chemical Corp. A $\mathrm{KCl}$ extract prepared from rat brain membranes or purified PLC- $\beta_{1}$ (see below) was used as the source of PLC. Stripped $\mathrm{GH}_{3}$-cell membranes or phospholipid vesicles containing cholate-soluble membrane proteins (see below) were used as the source of $G_{p}$. Incubations also contained nucleotides (GTP[S] or adenosine $5^{\prime}-[\gamma$-thio $]$ trisphosphate (ATP[S]) from Boehringer Mannheim, or GTP or ATP from Sigma) at indicated concentrations, added with equimolar $\mathrm{MgCl}_{2}$. Reactions at $37^{\circ} \mathrm{C}$ were initiated after a $60 \mathrm{~min}$ preincubation of $\mathrm{G}_{\mathrm{p}}$ and $\mathrm{PLC}$ at $0^{\circ} \mathrm{C}$ conducted in the absence of $\mathrm{CaCl}_{2}, \mathrm{MgCl}_{2}$, $\mathrm{NaCl}$, nucleotides and $\left[{ }^{3} \mathrm{H}\right] \mathrm{PtdIns} P_{2}$. Incubations were terminated by addition of $100 \mu \mathrm{l}$ of $10 \%$ (w/v) trichloroacetic acid plus $50 \mu \mathrm{l}$ of BSA $(10 \mathrm{mg} / \mathrm{ml})$. After $10 \mathrm{~min}$ on ice, reaction tubes were centrifuged at $1000 \mathrm{~g}$ for $30 \mathrm{~min}$ and the supernatants were analysed by liquid-scintillation counting by using Ecolume (ICN Biomedicals). Reaction products consisted exclusively of $\left[{ }^{3} \mathrm{H}\right] \operatorname{Ins}(1,4,5) P_{3}$ and $\operatorname{Ins}(1,4) P_{2}[22]$.

\section{Preparation of stripped membranes and membrane cholate extracts}

$\mathrm{GH}_{3}$-cell membranes were prepared as previously described [22] and were thoroughly washed by resuspension and centrifugation at $10000 \mathrm{~g}$ in $0.02 \mathrm{M}$-Tris/ $1 \mathrm{~mm}-\mathrm{MgCl}_{2} / 2 \mathrm{~mm}$-EGTA, $\mathrm{pH} 7.5$, to remove cytosolic PLC. Membrane pellets were re-

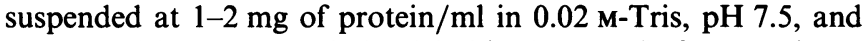
treated with $3 \mathrm{~mm}-N$-ethylmaleimide (NEtMal) for $30 \mathrm{~min}$ at $0{ }^{\circ} \mathrm{C}$, followed by $3 \mathrm{~mm}$-dithiothreitol to inactivate the guaninenucleotide-insensitive portion of the membrane PLC [22]. The membranes were adjusted to $2 \mathrm{~mm}$-EGTA and $1.0 \mathrm{M}-\mathrm{KCl}$ and placed on a platform rocker for $60 \mathrm{~min}$ at $4{ }^{\circ} \mathrm{C}$. Membranes were recovered by centrifugation at $20000 \mathrm{~g}$ for $45 \mathrm{~min}$ and resuspended to $1-2 \mathrm{mg}$ of protein $/ \mathrm{ml}$ in $0.02 \mathrm{M}$-Tris $/ 3.3 \mathrm{mM}$ EGTA, pH 7.5. The NEtMal-treated $\mathrm{KCl}$-extracted membranes are referred to as 'stripped', and were shown in our previous study [22] to lack PLC activity but to contain $G_{p}$ activity.

For preparation of cholate extracts, stripped membranes were resuspended to $1-2 \mathrm{mg}$ of protein $/ \mathrm{ml}$ in $0.02 \mathrm{M}$-Tris $/ 1 \mathrm{mM}$ EDTA/1 mM-dithiothreitol, $\mathrm{pH} \mathrm{8.0,} \mathrm{containing} 2.5 \mu \mathrm{g}$ of aprotinin $/ \mathrm{ml}$. Solid sodium cholate was added to $1.0 \%(\mathrm{w} / \mathrm{v})$ and the suspension was placed on a platform rocker for $60 \mathrm{~min}$ at $4{ }^{\circ} \mathrm{C}$. The membrane cholate extract was isolated as the supernatant of a centrifugation at $100000 \mathrm{~g}$ for $60 \mathrm{~min}$. The cholate extract was concentrated to the desired volume with a Centriprep-10 device (Amicon Corp.).

\section{Preparation of phospholipid vesicles reconstituted with $\mathbf{G H}_{3}$-cell membrane cholate extract}

Cholate extracts from stripped membranes were mixed with a suspension of PtdSer and PtdEtn to form a mixed detergentlipid-protein micelle. A cholate extract prepared from membranes of $5 \times 10^{7}$ cells was generally concentrated to $0.5-1.0 \mathrm{ml}$ and mixed with $0.15 \mathrm{ml}$ of a sonicated PtdSer/PtdEtn preparation (prepared by vortex-mixing and bath-sonicating $2.5 \mathrm{mg}$ of each lipid in $1 \mathrm{ml}$ of $0.02 \mathrm{M}$-Tris/1 mM-EDTA/1 mM-dithiothreitol, $\mathrm{pH} 8.0$, plus $2.5 \mu \mathrm{g}$ of aprotinin $/ \mathrm{ml}$ ). Phospholipid vesicles (also termed 'liposomes') were formed by dialysis for $18 \mathrm{~h}$ against $1000 \mathrm{vol}$. of $0.02 \mathrm{M}$-Tris $/ 1 \mathrm{~mm}$-EDTA/1 mM-dithiothreitol, $\mathrm{pH}$ 8.0. Vesicles were isolated by centrifugation at $100000 \mathrm{~g}$ for $120 \mathrm{~min}$ and resuspended in $0.02 \mathrm{~m}$ Tris/3.3 mM-EGTA, $\mathrm{pH} 7.5$, to a lipid concentration of $10 \mathrm{mg} / \mathrm{ml}$. When unpurified cholate membrane extracts were used as the source of protein, vesicles incorporated approx. $0.1 \mathrm{mg}$ of protein $/ \mathrm{mg}$ of lipid. Purified bovine brain $G_{o}$ (generously provided by $R$. Iyengar, Mount Sinai School of Medicine, New York, NY, U.S.A.), recombinant $\mathrm{G}_{\mathrm{z}} \propto$ subunit (generously provided by $P$. Casey, Duke University, Durham, NC, U.S.A.) and purified brain $\beta-\gamma$ subunits (also provided by $\mathrm{P}$. Casey) were incorporated into phospholipid vesicles by similar dialysis techniques.

\section{Preparation of crude and purified PLC- $\beta_{1}$}

The rat brain membrane PLC was prepared by homogenizing fresh rat brains in 7 vol. of $0.02 \mathrm{M}$-Hepes $/ 0.25 \mathrm{M}$-sucrose $/ 2 \mathrm{~mm}$ EGTA/2 mM-EDTA/0.1 mM-dithiothreitol/0.4 mM-phenylmethanesulphonyl fluoride plus $0.5 \mu \mathrm{g}$ of leupeptin $/ \mathrm{ml}$ and the homogenate was centrifuged at $10000 \mathrm{~g}$ for $30 \mathrm{~min}$. Pellets were washed twice by centrifugation in a large volume of

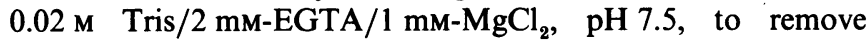
cytosolic PLC thoroughly. The final membrane pellet was resuspended in $0.02 \mathrm{M}$-Tris $/ 2 \mathrm{~mm}-\mathrm{EGTA} / 0.5 \mathrm{M}-\mathrm{KCl}, \mathrm{pH} 7.5$, placed on a platform rocker for $60 \mathrm{~min}$ at $4{ }^{\circ} \mathrm{C}$ and centrifuged at $100000 \mathrm{~g}$ for $60 \mathrm{~min}$. The supernatant was removed, diluted 5fold to decrease the $\mathrm{KCl}$ to $0.1 \mathrm{M}$, concentrated to $1-2 \mathrm{mg}$ of protein $/ \mathrm{ml}$ with a Centricon-10 apparatus and stored frozen at $-20^{\circ} \mathrm{C}$. This PLC preparation is referred to as ' $\mathrm{KCl}$ extract' and is known to contain principally PLC- $\beta_{1}$ (see the Results section). PLC- $\beta_{1}$ was purified from a fresh $\mathrm{KCl}$ extract by the procedure of Lee et al. [23] with modifications. Sequential chromatography on DEAE-cellulose, heparin-agarose, phenylSepharose and Mono Q was employed. The chromatography on phenyl-Sepharose (Pharmacia LKB Biotechnology) replaced the TSK-Phenyl-5PW step of Lee et al. [23]. Material from the heparin-agarose step was adjusted to $3 \mathrm{M}-\mathrm{KCl}$, and the pool was

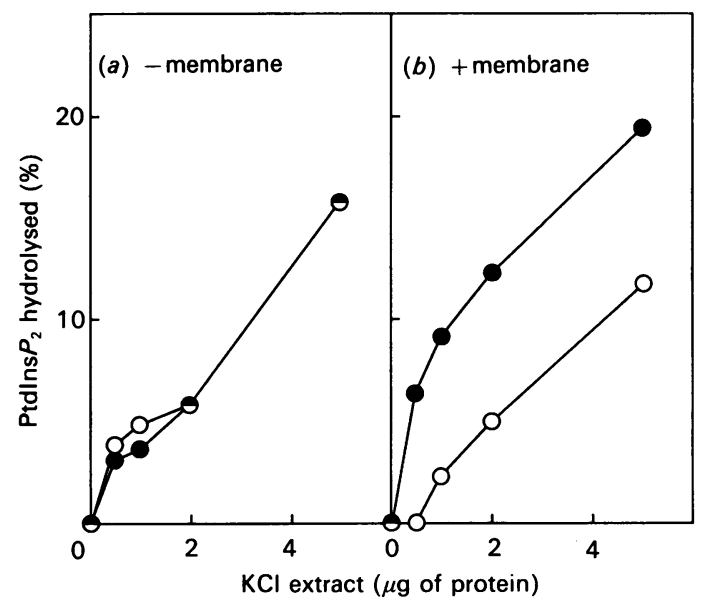

Fig. 1. The solubilized membrane PLC regains GTP[S]-stimulated activity upon co-incubation with stripped membranes

The solubilized membrane PLC was prepared from rat brain membranes by $\mathrm{KCl}$ extraction ( $\mathrm{KCl}$ extract) as described in the Materials and methods section. Stripped membranes from $\mathrm{GH}_{3}$ cells were prepared by treatment with $\mathrm{NEtMal}$ and extraction with $\mathrm{KCl}$ as described. Hydrolysis of $\left[{ }^{3} \mathrm{H}\right] \mathrm{PtdIns} P_{2}$ was determined in standard incubations conducted in the absence $(O)$ or presence $(O)$ of $10 \mu \mathrm{M}$ GTP[S]. Panels $(a)$ and $(b)$ show incubations with indicated amounts of $\mathrm{KCl}$ extract incubated alone or with $30 \mu \mathrm{g}$ of stripped membranes, respectively. A zero-time incubation value representing less than $2 \%$ of the total $\left[{ }^{3} \mathrm{H}\right] \mathrm{PtdIns} \boldsymbol{P}_{2}$ substrate has been subtracted from all values. Ordinate values represent $100 \times$ d.p.m. of acid-soluble ${ }^{3} \mathrm{H} /$ total d.p.m. of $\left[{ }^{3} \mathrm{H}\right] \mathrm{PtdIns} P_{\mathrm{z}}(\%)$. Note that membranes alone (ordinate value in $b$ ) lacked PLC activity. 


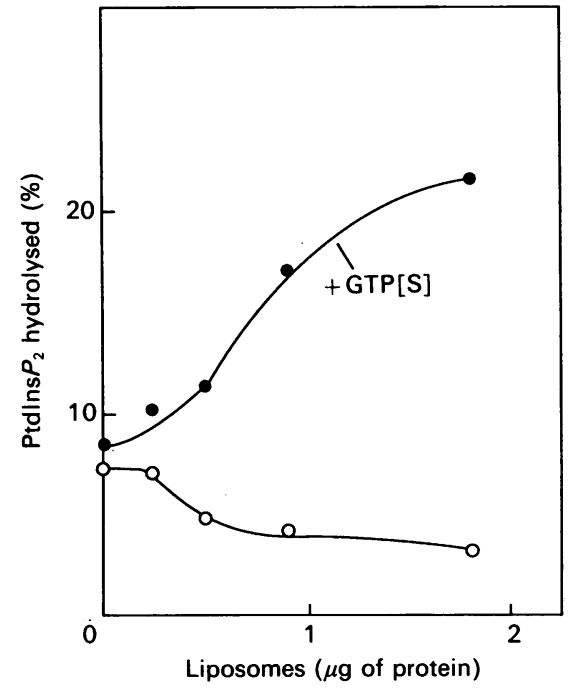

Fig. 2. Reconstitution of GTP[S] stimulation of PLC activity with phospholipid vesicles containing $\mathbf{G}_{\mathrm{p}}$

$\left[{ }^{3} \mathrm{H}\right]$ PtdIns $P_{2}$ hydrolysis was determined for incubations which included $2 \mu \mathrm{g}$ of rat brain $\mathrm{KCl}$ extract plus the indicated amounts of phospholipid vesicles (liposomes) containing cholate-soluble membrane proteins : $100 \mu \mathrm{M}$-GTP[S] was included where indicated by 0 . Phospholipid vesicles were prepared as described in the Materials and methods section by using a membrane cholate extract.

applied at $1 \mathrm{ml} / \mathrm{min}$ to a $15 \mathrm{ml}$ phenyl-Sepharose column equilibrated in $0.02 \mathrm{M}$-Hepes/3.3 mM-EGTA/0.1 mM-dithiothreitol/3.0 M-KCl/0.5 $\mu \mathrm{g}$ of leupeptin $/ \mathrm{ml}, \mathrm{pH} 7.0$. The column was washed in $50 \mathrm{ml}$ of this buffer, followed by $150 \mathrm{ml}$ of a similar buffer adjusted to $2.0 \mathrm{M}-\mathrm{KCl}$. The column was eluted with a $200 \mathrm{ml}$ linear gradient of a similar buffer containing from $2.0 \mathrm{M}$ - to $0 \mathrm{KCl}$, followed by a $200 \mathrm{ml}$ wash in the buffer at $0 \mathrm{KCl}$. Fractions eluted at $0.3-0 \mathrm{M}-\mathrm{KCl}$ containing PLC- $\beta_{1}$ were pooled, dialysed to $0 \mathrm{KCl}$, concentrated and loaded on to the Mono Q column as described by Lee et al. [23].

\section{Immunoprecipitation of PLC and G-proteins}

Immunodepletion studies were conducted with rabbit polyclonal antisera purified by chromatography on Protein A-Sepharose [24]. For each experiment, an equivalent protein amount of purified IgG prepared in parallel from non-immune rabbit serum was used as a control. Purified IgG fractions were concentrated to the original serum volume. IgG purification was essential, since proteins in crude serum were incorporated into phospholipid vesicles and strongly inhibited GTP[S]-stimulated PLC activity in the reconstituted system. Immunoprecipitations of G-proteins from cholate extracts or of PLC from $\mathrm{KCl}$ extracts were conducted under similar antibody-excess conditions. For PLC- $\beta_{1}$ immunoprecipitations, $60 \mu \mathrm{g}$ of purified rabbit anti-PLC IgG was incubated with $40 \mu \mathrm{g}$ of $\mathrm{KCl}$ extract. For G-protein immunoprecipitation, $120 \mu \mathrm{g}$ of purified rabbit anti-G-protein peptide IgG was incubated with $160 \mu \mathrm{g}$ of cholate-extracted membrane protein. Fractions were incubated with primary antibodies for $1 \mathrm{~h}$ on ice, followed by a second $1 \mathrm{~h}$ incubation with Protein A-Sepharose (obtained from Sigma). Immunodepleted supernatants were obtained by centrifugation at $12000 \mathrm{~g}$ for $20 \mathrm{~min}$. The extent of immunodepletion was evaluated by analysis of supernatants by SDS/PAGE on $10 \%$-polyacrylamide gels, followed by immunoblotting analysis by described methods [25], except that ${ }^{125}$ I-Protein A (DuPont-New England Nuclear; $0.1 \mu \mathrm{C}_{\mathrm{i}} / \mathrm{ml}$ ) was used as the secondary reagent for antibody detection. Antisera used in this study were; anti-PLC- $\beta_{1}$ antibody, generously provided by S. G. Rhee, N.I.H., Bethesda, MD, U.S.A.; antisera GO/1 (against $\mathrm{G}_{0} \propto C$-terminal peptide), EC/1

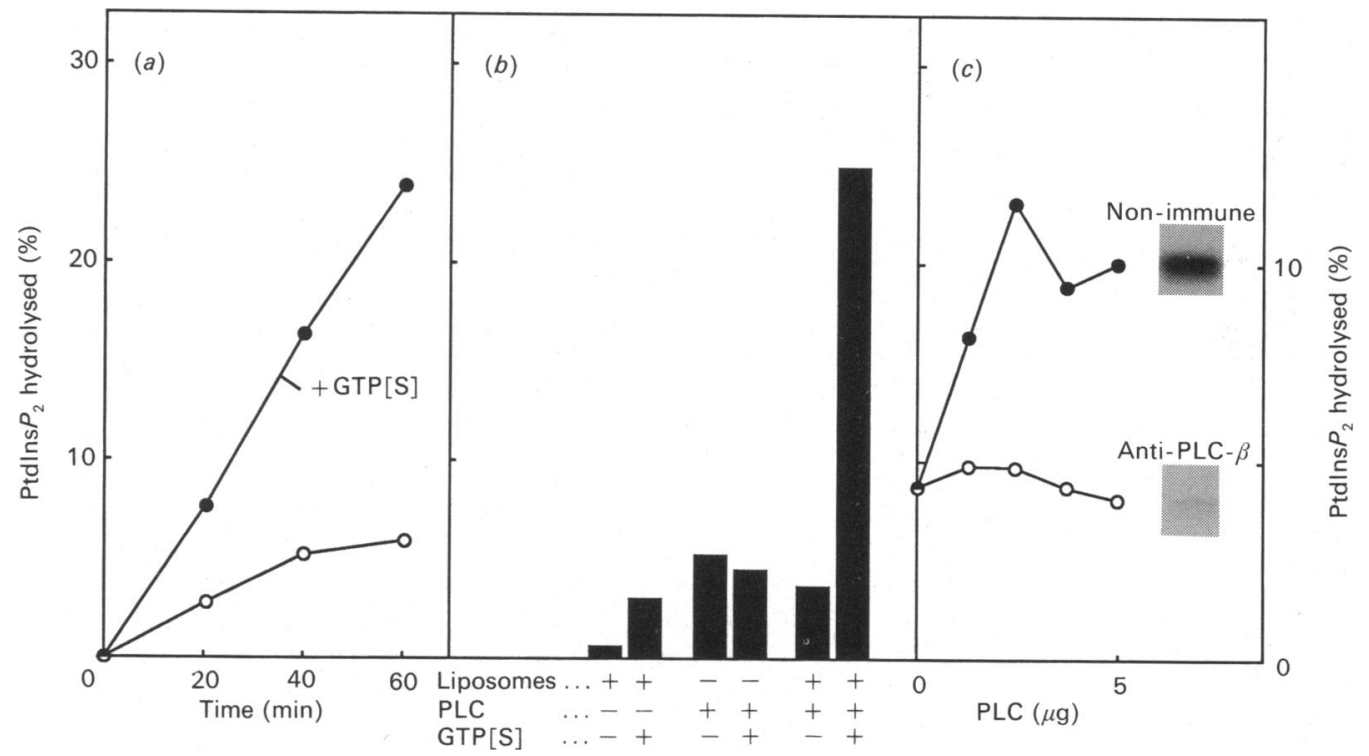

Fig. 3. Properties of the reconstituted $G_{\mathrm{p}}$-regulated PLC

(a) $\left[{ }^{3} \mathrm{H}\right] \mathrm{PtdIns} P_{2}$ hydrolysis was determined for complete incubations containing rat brain PLC and membrane-protein-containing liposomes as described in the legend to Fig. 2. Incubations were conducted for the indicated times either without $(O)$ or with $(O) 100 \mu \mathrm{M}-\mathrm{GTP}[\mathrm{S}]$. $(b)$ The requirements for GTP[S]-stimulated hydrolysis in the reconstituted system were determined in 60 min incubations which included the components indicated. $(c)$ The requirement of PLC- $\beta_{1}$ for GTP[S]-stimulated hydrolysis in the reconstituted system was determined in 60 min incubations which included $100 \mu \mathrm{M}$-GTP[S], $2 \mu \mathrm{g}$ of phospholipid-vesicle-incorporated membrane protein and the indicated amounts of rat brain PLC preparation. PLC preparations were treated before assay with either non-immune (O) or PLC $\beta_{1}$-specific immune sera (O) to immunoprecipitate PL C- $\beta_{1}$ as described in the Materials and methods section. The extent of immunodepletion was assessed in Western-blotting studies, which indicated $90 \%$ removal of PLC- $\beta_{1}$ (insets show $150 \mathrm{kDa}$ region of immunoblot). 
(against $\mathrm{G}_{\mathrm{i}} 3 \alpha C$-terminal peptide), AS/7 (against $\mathrm{G}_{\mathrm{t}} \alpha C$-terminal peptide) and SW/l (against $\beta$-subunit $C$-terminal peptide) generously provided by A. Spiegel, N.I.H., Bethesda, MD, U.S.A.; and antiserum $\mathrm{RM} / \mathrm{l}$ (against $\mathrm{G}_{\mathrm{s}} \alpha C$-terminal peptide) purchased from DuPont-New England Nuclear.

\section{RESULTS}

Reconstitution of solubilized membrane PLC with membrane-associated $\mathbf{G}_{\mathrm{p}}$

Most of the PLC activity detected in $\mathrm{GH}_{3}$-cell membranes was shown to be solubilized by salt extraction [22]. The soluble PLC

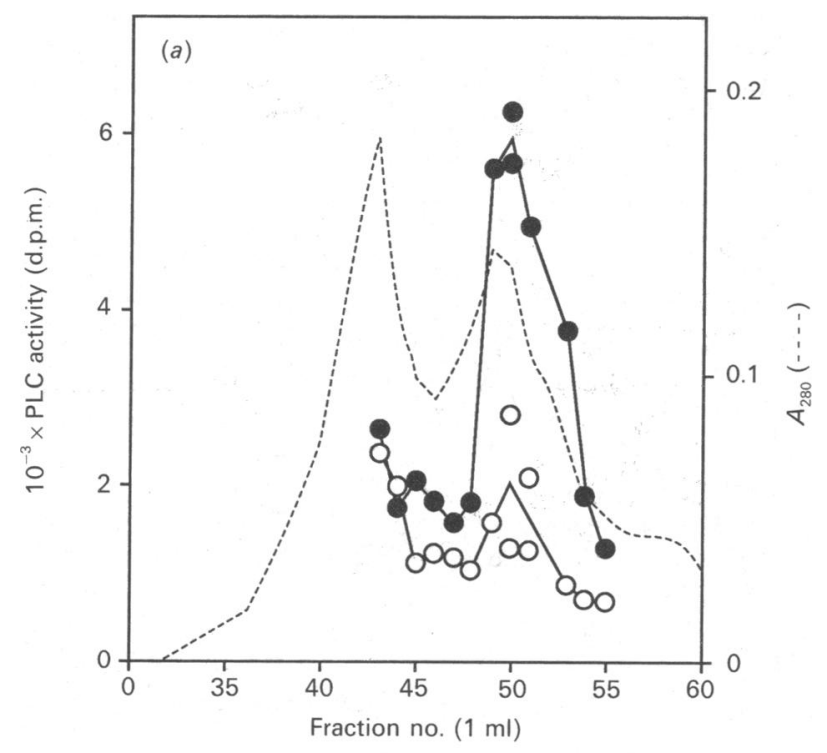

$49 \quad 50 \quad 51$
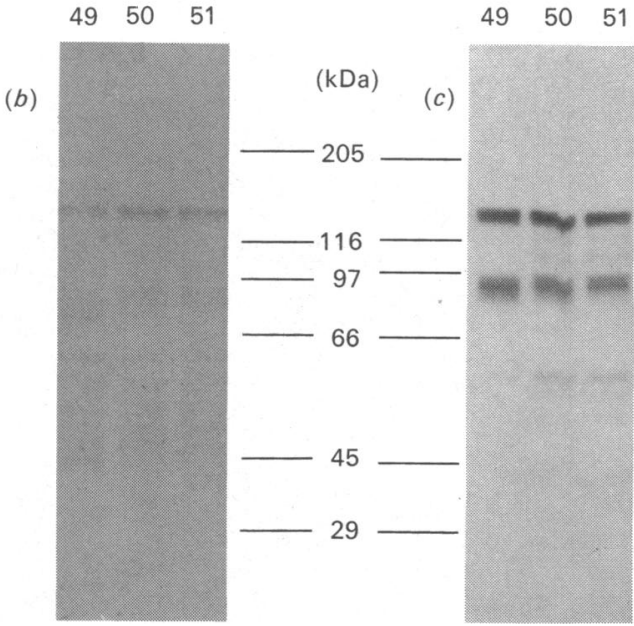

Fig. 4. $G_{p}$ regulates the activity of purified PLC- $\beta_{1}$

PLC $-\beta_{1}$ was purified as described in the Materials and methods section. (a) Fractions from the final Mono $\mathrm{Q}$ column step of purification were tested for PLC activity in the presence of $G_{p}$ containing liposomes as described in the legend to Fig. 2. Incubations were conducted either without (O) or with (O) $100 \mu \mathrm{M}-\mathrm{GTP}[S] . A_{280}$ values of column fractions are indicated (-..-). PLC elution in fractions $49-51$ occurred at $0.29 \mathrm{M}-\mathrm{KCl}$. (b) Column fractions representing about $10 \mu \mathrm{g}$ of protein were analysed by SDS/PAGE on $8 \%$-polyacrylamide gels. Protein was stained with Coomassie Blue. (c) Western-blotting studies were conducted after gel electrophoresis as in (b). Immunoblotting with PLC- $\beta_{1}$-specific rabbit antisera was conducted as described in the Materials and methods section. lacked GTP[S]-regulated activity, suggesting that it was extracted free of $G_{p}$. Restoration of the ionic strength of the $\mathrm{GH}_{3}$-cell enzyme preparation, or of a similarly prepared rat brain membrane enzyme, allowed reassociation of the soluble PLC with stripped membranes, and the PLC regained GTP[S]-stimulated activity. That $G_{p}$ was present in the PLC-deficient membrane was indicated by the fact that stripped membranes could be preactivated by GTP[S] [22]. In more recent studies, $\mathrm{G}_{\mathrm{p}}-\mathrm{PLC}$ coupling was found to be reconstituted by simply co-incubating the PLC with stripped $\mathrm{GH}_{3}$-cell membranes, as shown in Fig. 1 . The soluble membrane PLC was unresponsive to GTP[S] (Fig. 1a) and stripped $\mathrm{GH}_{3}$-cell membranes lacked PLC activity (Fig. $1 b$, point on ordinate). However, incubation of the PLC $(\mathrm{KCl}$ extract) with stripped membranes restored GTP[S]-stimulated PLC activity (Fig. 1b). The results indicated that the $\mathrm{GH}_{3}$-cell membrane $G_{p}$ could functionally couple with a solubilized brain membrane PLC.

\section{Regulation of solubilized membrane PLC by detergent- solubilized $G_{p}$ incorporated in phospholipid vesicles}

In additional experiments (results not shown), cholate extraction was found to remove the membrane component, $G_{p}$, essential for restoring the GTP[S] regulation of PLC activity. This result suggested the possibility of reconstituting this component into phospholipid vesicles. Membrane proteins were cholate-solubilized from stripped membranes and incorporated by dialysis into PtdEtn/PtdSer vesicles. As shown in Fig. 2, the activity of the solubilized PLC was not altered by GTP[S] when tested alone (points on ordinate), but addition of membrane protein in phospholipid vesicles conferred GTP[S] stimulation. Phospholipid vesicles lacking membrane protein or containing heat-denatured $\left(65^{\circ} \mathrm{C}\right.$ for $15 \mathrm{~min}$ ) protein did not restore GTP[S] regulation. GTP[S]-stimulated PtdIns $P_{2}$ hydrolysis was linear for at least $60 \mathrm{~min}$ in the reconstitution (Fig. $3 a$ ). GTP[S]-stimulated PLC activity required both the soluble membrane PLC and vesicle-incorporated membrane protein (Fig. $3 b$ ). Vesicles tested in the absence of the soluble PLC exhibited only low basal or GTP[S]-stimulated activity, resulting from residual PLC present in the stripped $\mathrm{GH}_{3}$-cell membranes from which cholate extracts were prepared.

\section{Reconstitution of GTP[S]-regulated activity with purified PLC- $\boldsymbol{\beta}_{1}$}

Most of the stimulated PLC activity detected in the reconstitution assay was due to the rat brain PLC- $\beta_{1}$ isoenzyme. PLC preparations immunodepleted of PLC- $\beta_{1}$ exhibited only background activity in the reconstitution (Fig. $3 c$ ). Additional evidence that $\mathrm{G}_{\mathrm{p}}$ regulated the activity of the PLC- $\beta_{1}$ isoenzyme was obtained by testing the purified enzyme. Fig. 4 shows the final step of PLC- $\beta_{1}$ purification on a Mono Q f.p.l.c. column. PLC activity in fractions 49-53 was GTP[S]-stimulated when $G_{p}$ containing vesicles were included in the reaction mixtures. Analysis of these column fractions by SDS/PAGE revealed one major $145 \mathrm{kDa}$ protein band, a protein doublet at about $90 \mathrm{kDa}$ and several minor lower-molecular-mass proteins. Immunoreactivity detected with PLC- $\beta_{1}$-specific antibody corresponded to the $145 \mathrm{kDa}, 90 \mathrm{kDa}$ and several lower-molecular-mass proteins, indicating that PLC fragments were present in the purified fraction, as previously reported [23]. The results indicated that the activity of highly purified PLC $-\beta_{1}$ can be regulated by $\mathbf{G}_{\mathrm{p}}$.

\section{Reconstituted $G_{p}-$ PLC coupling is similar to that observed in membranes}

As shown in Fig. 5, PLC- $\beta_{1}$ activity was $\mathrm{Ca}^{2+}$-activated but not GTP[S]-regulated when assayed alone (Fig. $5 a$ ). With $\mathrm{G}_{\mathrm{p}}$-con- 


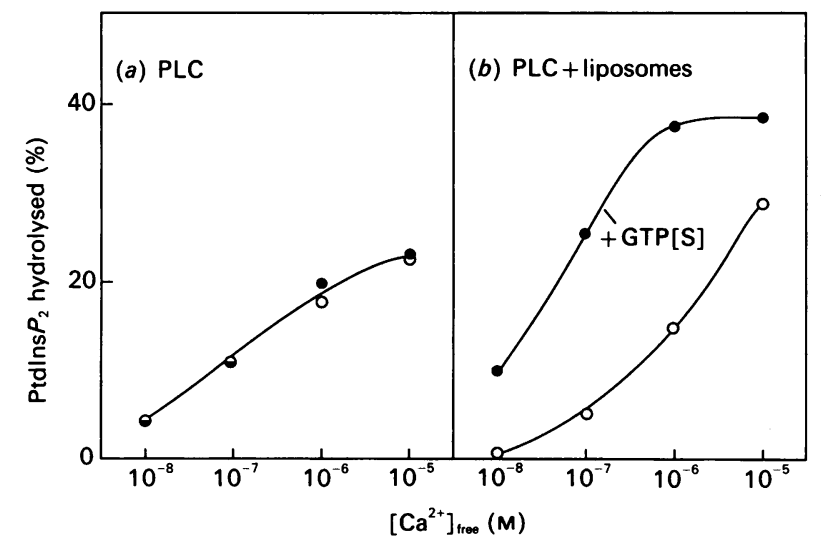

Fig. 5. $\mathrm{Ca}^{2+}$ stimulation of PLC activity in the absence or presence of $\mathbf{G}_{p}$

$\left[{ }^{3} \mathrm{H}\right] \mathrm{PtdIns} \mathrm{P}_{2}$ hydrolysis was determined in parallel incubations which included PLC- $\beta_{1}$ without $(a)$ or with $(b)$ phospholipid vesicles containing membrane proteins. Reactions containing the indicated concentrations of free $\mathrm{Ca}^{2+}$ and $100 \mu \mathrm{M}-\mathrm{GTP}[\mathrm{S}]$ where indicated

(O). Other conditions were as specified in the legend to Fig. 2.

taining vesicles, GTP[S] stimulation was observed at low $\mathrm{Ca}^{2+}$ concentrations (Fig. $5 b$ ). Preferential stimulation by GTP[S] at low $\mathrm{Ca}^{2+}$ concentrations indicated that the reconstitution exhibited characteristics similar to those reported for studies of G-protein-regulated PLC in intact membranes [6,7,21].

Nucleotide stimulation of PLC activity in the reconstitution exhibited characteristics expected for G-proteins [18]. GTP[S] stimulation of hydrolysis was observed at $0.1-100 \mu \mathrm{M}$ (Fig. $6 a$ ). Guanosine $5^{\prime}$-[ $\beta \gamma$-imido]triphosphate (p[NH]ppG) was a much less effective activator (Table 1). Stimulation of PLC activity was observed with $\mathrm{AlCl}_{3} / \mathrm{Mg}^{2+} / \mathrm{NaF}$ (AMF; Table 1), presumably acting as the $\mathrm{AlF}_{4}{ }^{-}$complex [18]. Activation by nucleotides and
Table 1. Nucleotide stimulation of PLC activity reconstituted with phospholipid vesicles containing cholate-soluble proteins

$\left[{ }^{3} \mathrm{H}\right] \mathrm{PtdIns} P_{2}$ hydrolysis was determined in standard reconstitution assays with phospholipid vesicles containing membrane proteins and rat brain PLC. Incubations were for $60 \mathrm{~min}$ at $37^{\circ} \mathrm{C}$ and contained the indicated concentrations of nucleotides along with equimolar $\mathrm{MgCl}_{2}$. The results from three independent experiments are shown. Means and ranges of duplicate determinations are indicated.

\begin{tabular}{cc}
\hline & $\begin{array}{c}\text { PtdIns } P_{2} \\
\text { hydrolysis } \\
\text { (\% of control })\end{array}$
\end{tabular}

\begin{tabular}{lr}
\hline None & $100 \pm 16$ \\
GTP[S] $(100 \mu \mathrm{M})$ & $368 \pm 40$ \\
GTP $(100 \mu \mathrm{M})$ & $116 \pm 12$ \\
ATP[S] $(100 \mu \mathrm{M})$ & $100 \pm 12$ \\
None & $100 \pm 13$ \\
GTP[S] $(100 \mu \mathrm{M})$ & $370 \pm 27$ \\
AMF & $538 \pm 22$ \\
None & $100 \pm 7$ \\
GTP[S] $(100 \mu \mathrm{M})$ & $354 \pm 34$ \\
p[NH]ppG $(1 \mathrm{mM})$ & $178 \pm 29$ \\
GTP $(1 \mathrm{mM})$ & $44 \pm 7$ \\
GTP[S]+p[NH]ppG & $206 \pm 15$ \\
GTP[S]+GTP & $100 \pm 8$
\end{tabular}

AMF required phospholipid vesicles containing $G_{p}$. ATP[S], GTP (Table 1), GDP (results not shown) and guanosine $5^{\prime}-[\beta$ thio]diphosphate (GDP[S]) (Fig. 6a) did not activate the reconstituted PLC.

GTP and GDP[S] antagonized the stimulatory effects of GTP[S] (Table 1 and Fig. $6 a$ ). The antagonistic properties of GTP were used to characterize GTP[S] activation. If added at zero
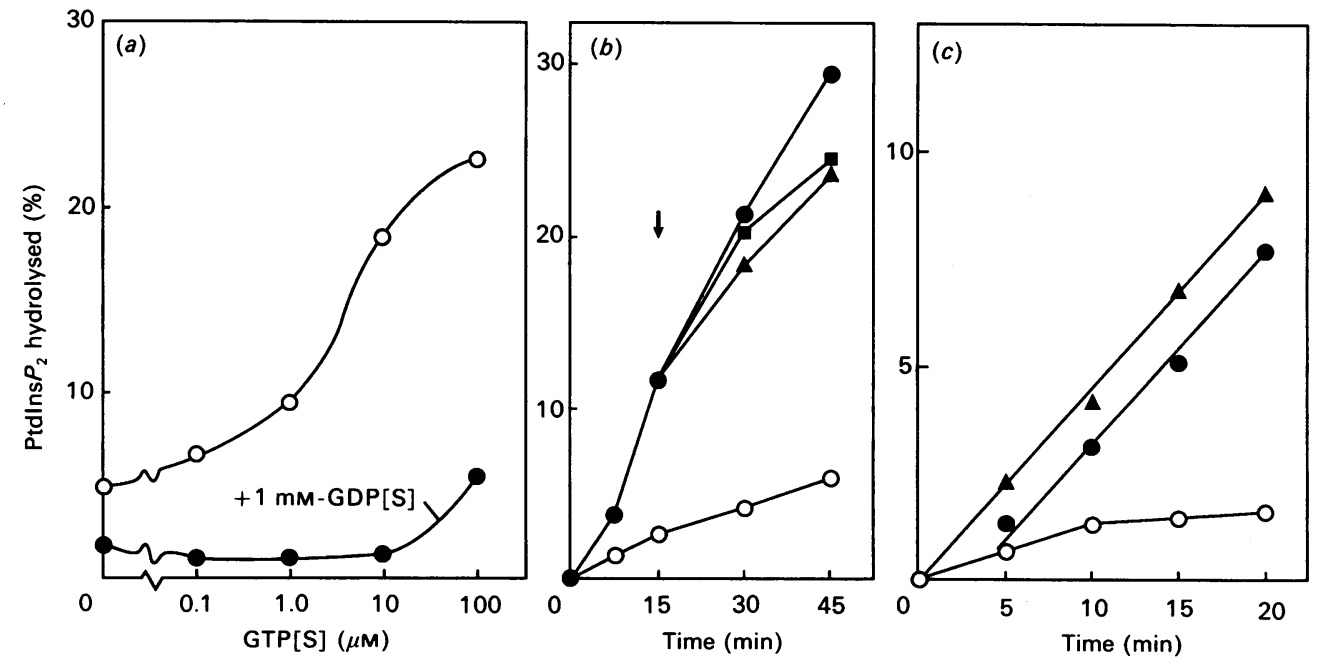

Fig. 6. Nucleotide stimulation of reconstituted PLC- $\boldsymbol{\beta}_{1}$

(a) $\left[{ }^{3} \mathrm{H}\right] \mathrm{PtdIns} \mathrm{P}_{2}$ hydrolysis was determined in incubations similar to those described in the legend of Fig. 2, except that the concentrations of GTP[S] were varied as indicated. Incubations also included $1 \mathrm{~mm}-\mathrm{GDP}[\mathrm{S}]$ as indicated $(\bullet)$. (b) GTP[S] stimulation of the reconstituted PLC is quasi-irreversible. Incubations containing PLC and phospholipid vesicles were conducted for the indicated times in the absence $(O)$ or in the presence $(\boldsymbol{O}, \mathbf{\Delta}, \mathbf{A})$ of $100 \mu \mathrm{M}-\mathrm{MgGTP}[\mathrm{S}]$. At the time indicated by the arrow, parallel incubations were supplemented with $1 \mathrm{mM}-\mathrm{MgCl}_{2}(\boldsymbol{\Delta})$ or $1 \mathrm{~mm}-\mathrm{MgGTP}(\boldsymbol{\square})$. Data shown are means of duplicate determinations which differed from each other by less than $15 \%$ of the absolute value. (c) GTP[S] stimulation of the reconstituted PLC exhibits a latency. Reactions containing PLC and $\mathrm{G}_{\mathrm{p}}$-containing liposomes were incubated for the indicated times in the absence $(O)$ or presence $(\Theta)$ of $100 \mu \mathrm{M}-\mathrm{GTP}[S]$. A parallel incubation was conducted $(\Delta)$ in which phospholipid vesicles were preincubated with GTP[S] for $7.5 \mathrm{~min}$ at $37^{\circ} \mathrm{C}$ before addition of PLC. Additional control experiments (results not shown) indicated that removal of the lag for activation required inclusion of GTP[S] in the preincubation with vesicles. Data shown are means of duplicate determinations which differed from each other by less than $15 \%$ of the absolute value. 


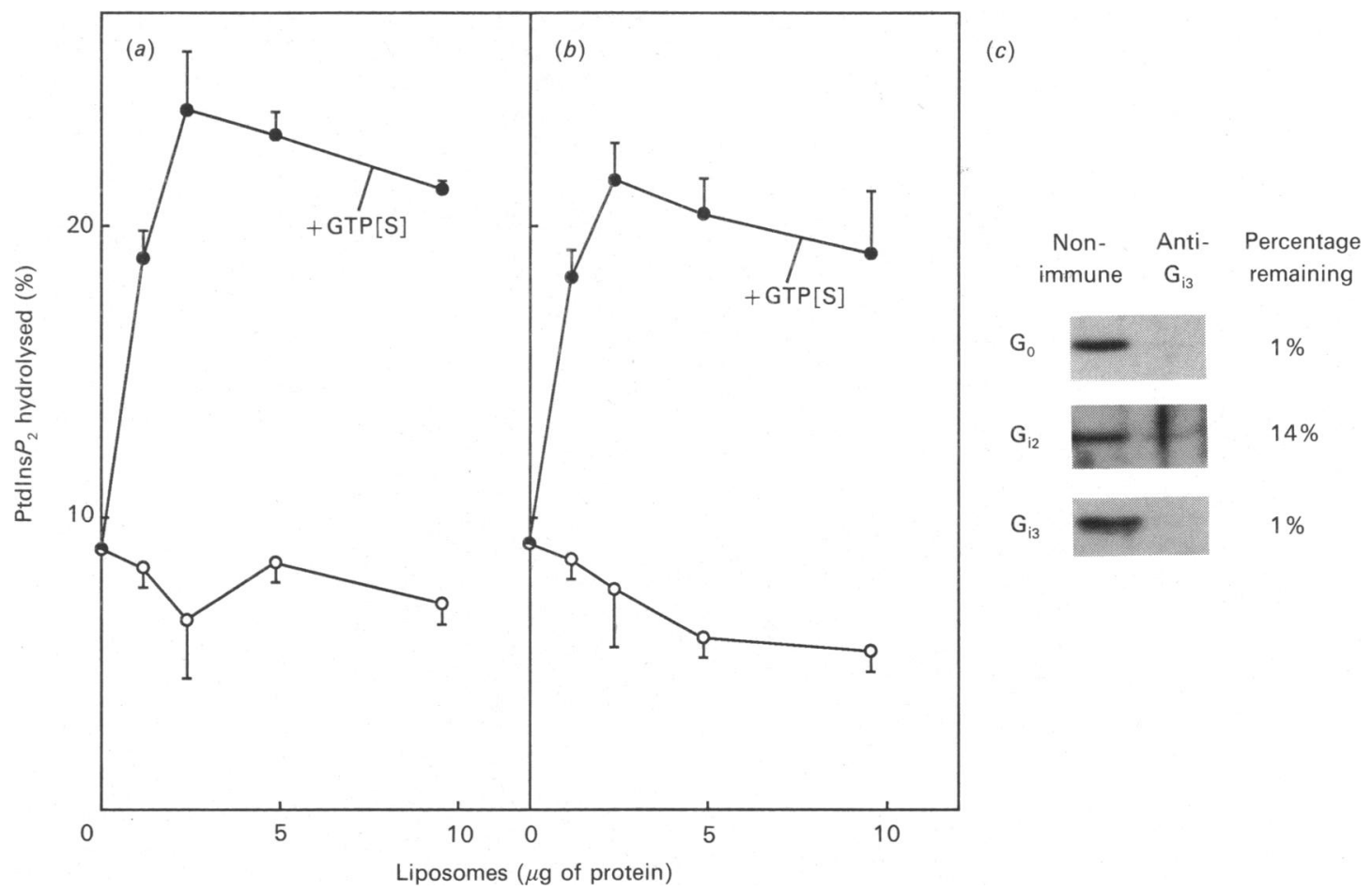

Fig. 7. $G_{p}$ activity is present in cholate extracts immunodepleted of $G_{0}$ and $G_{i}$

(a) and (b) Cholate extracts of stripped $\mathrm{GH}_{3}$-cell membranes were treated with purified IgG fractions of non-immune $(a)$ or $\mathrm{G}_{13}$-peptide-specific immune $(b)$ sera. After Protein A-Sepharose adsorption, depleted supernatants were incorporated into phospholipid vesicles by dialysis. The recovered liposomes were assayed with $2 \mu \mathrm{g}$ of rat brain PLC in the absence $(O)$ or presence $(O)$ of $100 \mu \mathrm{M}-\mathrm{GTP}[\mathrm{S}]$ for ability to hydrolyse $\left[{ }^{3} \mathrm{H}\right] \mathrm{Ptd} I n s P_{2}$. Data shown are means of duplicate determinations with range indicated. $(c)$ Treated cholate extracts were analysed by Westernblotting procedures for their G-protein content. Anti-peptide antisera GO/1, AS/7 and EC/1 were used at 1:100 dilution for detection of $G_{0}, G_{i 2}$ and $G_{i 3}$ respectively.

time, GTP completely blocked stimulation by GTP[S] (Table 1), whereas delayed addition of GTP had no effect on the rate of GTP[S]-stimulated PtdIns $P_{2}$ hydrolysis (Fig. 6b). This result indicated that GTP[S] stimulation was quasi-irreversible, as had been observed for other G-protein-regulated processes [18]. Activation by GTP[S] exhibited a distinct lag of 2-3 min (Fig. $6 c$, O). Preincubation of phospholipid vesicles with GTP[S] before PLC addition eliminated the latency to activation (Fig. $6 c, \mathbf{\Delta}$ ).

\section{Characterization of $\mathbf{G H}_{3}$-cell membrane $\mathbf{G}_{\mathbf{p}}$}

The reconstitution of GTP[S]-activated PLC activity provided an assay to monitor the purification of the $\mathrm{GH}_{3}$-cell $\mathrm{G}_{\mathrm{p}}$ and has been used to establish the chromatographic properties of $G_{p}$ on DEAE-Sephacel, Ultrogel AcA 34, heptylamine-Sepharose and hydroxyapatite columns (results not shown). In each case, $G_{p}$ was co-eluted with the major peak of GTP $\left[{ }^{35} \mathrm{~S}\right]$-binding, which corresponded to known heterotrimeric G-proteins $\left(G_{0}, G_{i}\right.$ and $G_{s}$ ) $[26,27]$. Previous studies had demonstrated that regulation by thyrotropin-releasing hormone (plus GTP) of PLC activity in $\mathrm{GH}_{3}$-cell membranes was CT- and PT-insensitive [6,7,21]. The apparent co-elution of $G_{p}$ with known $G$-proteins on several columns prompted studies to examine the similarity of $G_{p}$ to these G-proteins. In addition, it was important to verify that the $\mathrm{G}_{\mathrm{p}}$ detected by reconstitution with PLC- $\beta_{1}$ corresponded to the PT- and CT-insensitive $G_{p}$ inferred from intact $\mathrm{GH}_{3}$-cell and membrane studies [7,21]. $\mathrm{GH}_{4} \mathrm{C}_{1}$ cells, closely related to $\mathrm{GH}_{3}$ cells, are known to contain $G_{13}, G_{i 2}, G_{o}$ and $G_{s}$ ([28]; S. E. Senogoles, unpublished work). Peptide-specific antisera to known G-proteins were used to immunodeplete G-proteins from $\mathrm{GH}_{3}$-cell membrane cholate extracts and the extracts were incorporated into phospholipid vesicles for testing with PLC- $\beta_{1}$.
As shown in Fig. $7(c)$, antibodies to a $G_{i 3}$ peptide completely depleted $G_{i 3}$ and $G_{o}$ from cholate extracts; $G_{i 2}$ was depleted by over $80 \%$. The results were consistent with the reported crossreactivity of this antibody [29]. Phospholipid vesicles prepared with the depleted extracts (Fig. $7 b$ ) exhibited $G_{p}$ activity that was indistinguishable from that of vesicles incorporated with control extracts (Fig. $7 a$ ). Since $\mathrm{G}_{\mathrm{i} 2}$ was not completely removed, an anti$\mathrm{G}_{\mathrm{t}}$-peptide antibody was also used and was found to deplete $96 \%$ of the $G_{i 2}$, with no resulting change in the apparent abundance of $G_{p}$ in the reconstitution assay (results not shown). Similar experiments were conducted with $\mathrm{G}_{\mathrm{s}}$-peptide-specific antisera, which depleted extracts of $G_{s}$ by $99 \%$ without loss of $G_{p}$ activity (results not shown). The results indicated that the $\mathrm{GH}_{3}$-cell $\mathrm{G}_{\mathrm{p}}$ is immunologically distinct from known $\mathrm{G}$-proteins present in these cells [28].

The reconstitution assay was also used to test the ability of several known G-proteins to regulate PLC- $\beta_{1}$ activity. As shown in Fig. 8(a), purified brain $\mathrm{G}_{\mathrm{o}}$ failed to confer GTP[S] regulation on PLC- $\beta_{1}$. However, inclusion of $G_{0}$ in phospholipid vesicles along with $G_{p}$ resulted in inhibition of $G_{p}$ activity. $G_{z}$, a Gprotein lacking sites for PT-catalysed ADP ribosylation, has been proposed as a possible PT-insensitive $G_{p}[30,31]$, and appears to be expressed in $\mathrm{GH}_{3}$ cells [31]. However, $\mathrm{G}_{\mathrm{z}}$ failed to support GTP[S] stimulation of PLC activity, but also inhibited $G_{p}$ activity when incorporated into phospholipid vesicles along with $\mathrm{GH}_{3}$-cell $\mathrm{G}_{\mathrm{p}}$ (Fig. 8b). A likely explanation for the inhibitory effects of these G-proteins was the inclusion of additional $\beta-\gamma$ subunits provided by these heterotrimers. This suggestion was confirmed by the experiment shown in Fig. 8(c), where inclusion of $\beta-\gamma$ subunits was found to inhibit the stimulation of PLC- $\beta_{1}$ by $G_{p}$. 


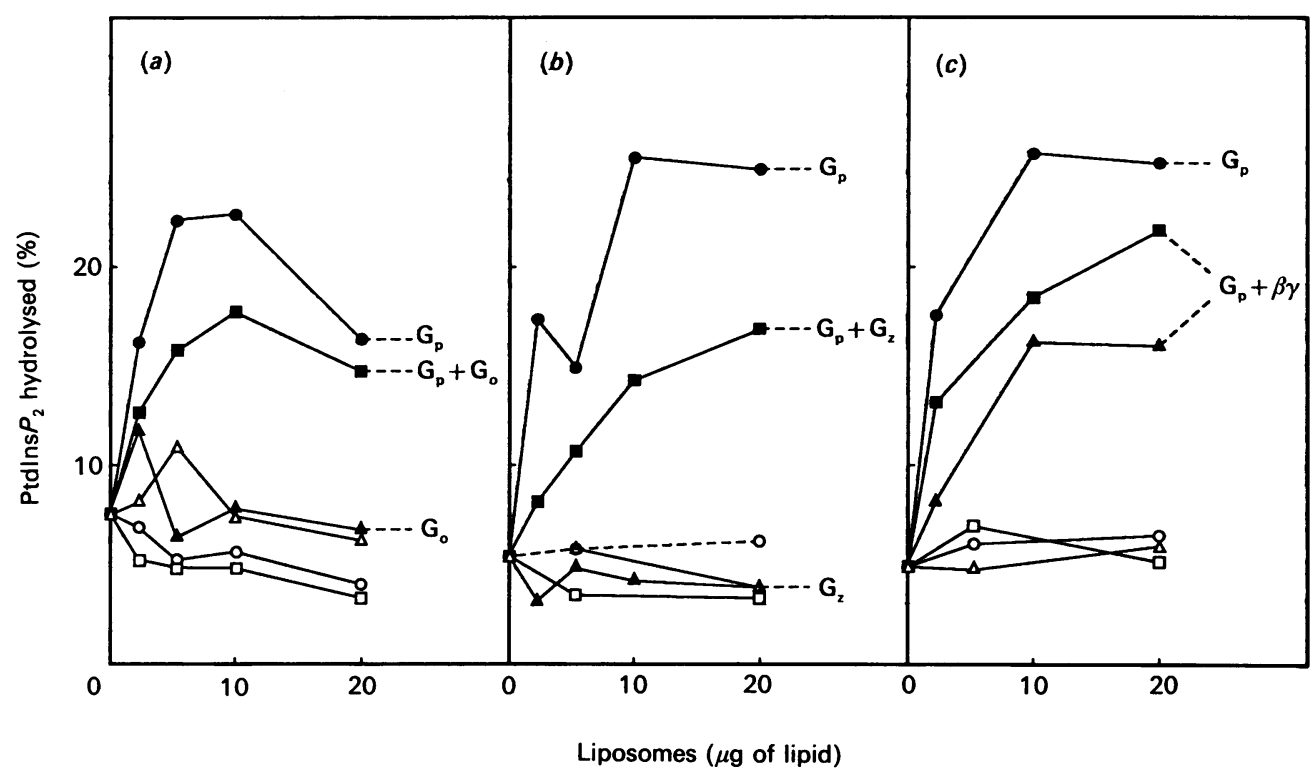

Fig. 8. $\beta-\gamma$ subunits inhibit $G_{p}$ activity in liposomes

Phospholipid vesicles of different compositions were prepared by detergent-dialysis methods. In each case, proteins were incorporated with $0.5-0.75 \mathrm{mg}$ of total lipid (PtdEtn plus PtdSer). After recovery by centrifugation, the liposomes were resuspended to $10 \mathrm{mg}$ of lipid/ml and tested for activity in the absence $(O, \triangle, \square)$ or in the presence of $(\boldsymbol{O}, \boldsymbol{\Delta}, \mathbf{\square})$ of $100 \mu \mathrm{M}-\mathrm{GTP}[\mathrm{S}]$, by using $2 \mu \mathrm{g}$ of PLC. (a) Liposomes were prepared with $\sim 150 \mu \mathrm{g}$ of cholate-soluble $\mathrm{GH}_{3}$-cell membrane protein $\left(\mathrm{O}, \mathbf{O} ; \mathrm{G}_{\mathrm{p}}\right)$, with $1.25 \mu \mathrm{g}$ purified $\mathrm{G}_{\mathrm{o}}\left(\triangle, \Delta ; \mathrm{G}_{\mathrm{o}}\right)$ or with both $\left(\square\right.$, $\left.\mathbf{\square} ; \mathrm{G}_{\mathrm{p}}+\mathrm{G}_{\mathrm{o}}\right)$. The amount of purified $G_{o}$ incorporated was equivalent to about 6 times that incorporated into the liposomes prepared from cholate extracts, as estimated from immunoblotting analysis (results not shown). (b) Liposomes were prepared with $\sim 150 \mu \mathrm{g}$ of cholate-soluble membrane protein from $\mathrm{GH}_{3}$-cell membranes $\left(O, \odot ; \mathrm{G}_{\mathrm{p}}\right)$, with $0.5 \mu \mathrm{g}$ of recombinant $\mathrm{G}_{\mathrm{z}} \alpha$ plus $1.5 \mu \mathrm{g}$ of purified $\beta-\gamma$ subunits $\left(\Delta, \Delta ; \mathrm{G}_{\mathrm{z}}\right)$ or with both $(\square, \square$; $G_{p}+G_{z}$ ). Incorporation of $G_{z} \alpha$ alone with $G_{p}$ produced liposomes which were not detectably different from those prepared with $G_{p}$ alone (results not shown). (c) Liposomes were prepared with $\sim 150 \mu \mathrm{g}$ of cholate-soluble membrane protein from $\mathrm{GH}_{3}$-cell membranes $\left(O\right.$, $\left.; \mathrm{O}_{\mathrm{p}}\right)$ or with cholate extract plus purified $\beta-\gamma$ subunits $(\square, \square, 0.5 \mu \mathrm{g} ;$ or $\Delta, \Delta, 1.5 \mu \mathrm{g})$. Liposomes prepared with purified $\beta-\gamma$ subunits contained about 3 times $(\boldsymbol{\square})$ and 6 times $(\boldsymbol{\Delta})$ the amount present in the liposomes prepared with cholate extract alone, as estimated from immunoblotting analysis (results not shown).

\section{DISCUSSION}

Although there is substantial indirect experimental evidence implicating GTP-binding proteins in receptor-mediated activation of PLC [2-5], the $\mathrm{G}_{\mathrm{p}} \mathrm{s}$ and PLCs involved in transduction have not been completely identified. The mechanisms of PLC activation by $G_{p} s$ have also not been fully elucidated. Identification of the components, as well as studies of mechanism, require the development of functional reconstitution assays into which $\mathrm{G}_{\mathrm{p}} \mathrm{s}$ and PLCs can be separately introduced. Such assays have been difficult to develop for the phosphoinositide signalling system, since all of the required components, including substrate, are membrane-associated.

Our previous studies [22] demonstrated that $\mathrm{G}_{\mathrm{p}}-\mathrm{PLC}$ coupling in $\mathrm{GH}_{3}$-cell membranes could be reversibly dissociated by high salt, which solubilized the PLC. The reconstitution of GTP[S]regulated PLC activity in the membrane required both the solubilized PLC and a membrane component, $G_{p}$. The present studies extended these findings, demonstrating that the $G_{p}$ required for reconstituting GTP[S]-stimulated PLC activity could be extracted with cholate and incorporated into phospholipid vesicles which conferred GTP[S] regulation on a solubilized membrane PLC. Reconstitution of regulated PLC activity convincingly displayed the nucleotide-specificity and fluoride-activation characteristics of the intact membrane system $[6,7]$ and of other G-protein-regulated processes [18]. This was important to establish, since numerous reports have documented nonspecific effects of nucleotides or fluoride on phosphoinositide hydrolysis which do not involve G-proteins [32-35].
The previous studies showed that an extrinsic $\mathrm{GH}_{3}$-cell membrane PLC could undergo reversible coupling with $G_{p}$ [22]. In the present studies, a heterologous reconstitution was achieved in which the $\mathrm{GH}_{3}$-cell $\mathrm{G}_{\mathrm{p}}$ regulated the activity of a brain extrinsic membrane PLC. Immunodepletion studies demonstrated that the isoenzyme responsible for activity in the reconstitution was PLC $-\beta_{1}$. In addition, it was shown that the membrane form of PLC- $\beta_{1}$ could be purified essentially to homogeneity without loss of its ability to couple with $\mathrm{G}_{\mathrm{p}}$. Since PLC- $\beta_{1}$ has not been detected immunologically in $\mathbf{G H}_{3}$ cells (T. F. J. Martin \& J. A. Kowalchyk, unpubished work), it is probable that the pituitary cell $G_{p}$ can regulate the activity of at least two distinct extrinsic membrane PLC isoenzymes, although the identity of the $\mathrm{GH}_{3}$-pituitary-cell enzyme remains to be established.

There may be several tissue-specific modes of $G_{p}-P L C$ coupling with employ distinct PLCs. At least five PLC isoenzymes have been fully purified and characterized [2,19]. Although guanine nucleotide stimulation of cytosolic PLC activity [36-38] has been reported, the role of cytosolic PLCs in signal transduction by Gprotein-linked receptors remains uncertain. Since GTP-dependent agonist regulation of PLC activity occurs in purified membrane preparations [2-5], it is important to elucidate the regulation of membrane PLC isoenzymes. Guanine nucleotide stimulation of activity has been reported for partially characterized platelet intrinsic membrane PLCs $[12,20,38]$. A soluble, possibly extrinsic membrane, $150 \mathrm{kDa}$ PLC distinct from PLC $\beta$ was reported to be regulated by an erythrocyte membrane $G_{p}$ [39]. Guanine-nucleotide-regulated PLC activity has been described for brain membranes [40,41], where the 
extrinsic membrane form of PLC- $\beta_{1}$ predominates [23]; antiPLC- $\beta$ antibody was shown to inhibit GTP[S] stimulation [42]. Recently, Smrcka et al. [17] demonstrated the regulation of a partially purified PLC- $\beta_{1}$ by purified $G_{\mathrm{q}}$. These and the results provided here for the highly purified enzyme indicate that PLC$\beta_{1}$ is one of the enzymes that is regulated by a PT-insensitive $G_{p}$.

Several distinct $G_{p}$ proteins regulate PLC activity in different systems. For systems in which agonist-regulated phosphoinositide hydrolysis is PT-sensitive, roles for $G_{o}$ and $G_{i}$ in coupling have received strong experimental support [11-15]. $G_{0}$ and $G_{i}$ substitute for the endogenous $G_{p}$ in PT-treated HL-60 cell membranes [11], and both were reported to activate a partially purified platelet membrane PLC [12]. In Xenopus oocytes, $G_{0}$, but not $G_{i}$, was found to enhance PT-sensitive receptor-mediated activation of a presumed PLC [15]. The identity of $\mathrm{G}_{\mathrm{p}} \mathrm{s}$ in PT-insensitive systems has also recently been clarified. Evidence that $\beta-\gamma$ subunits affected PT-insensitive receptor-mediated activation suggested that a heterotrimeric $\mathrm{G}$ protein was involved [43,44]. Recently, Taylor et al. [16] and Smrcka et al. [17] reported the purification of G-proteins with $42 \mathrm{kDa} \alpha$-subunits that were capable of activating PLCs. Smrcka et al. [17] reported that the purified G-proteins corresponded to $\mathrm{G}_{\mathrm{q}} / \mathrm{G}_{11}$, proteins inferred from cDNA sequencing [45], which lacked a site for ADP-ribosylation by PT. The $\mathrm{GH}_{3}$-cell $G_{p}$ identified by reconstitution in the present study is likely to be a related PT-insensitive $G_{p}$, since quantitative immunodepletion of $G_{i 2}, G_{i 3}, G_{o}$ and $G_{s}$ from cholate extracts failed to affect $G_{p}$ activity.

Our results suggest that PT-sensitive and -insensitive modes of $\mathrm{G}_{\mathrm{p}}-\mathrm{PLC}$ coupling may differ with respect to both the G-proteins and the PLC isoenzymes employed. PLC $-\beta_{1}$ was found not to be regulated by purified brain $\mathrm{G}_{\mathrm{o}}$. In addition, depletion of $\mathrm{GH}_{3}$-cell $G_{o}$ and $G_{1}$ proteins did not affect activity in the reconstitution. Lastly, during purification efforts, column fractions which contained $G_{o}$ or $G_{i}$, but not $G_{p}$, failed to confer guanine nucleotide regulation on PLC- $\beta_{1}$. These results stand in contrast with the evidence reviewed above for the role of $G_{i}$ and/or $G_{o}$ proteins in PT-sensitive PLC regulation in other tissues. These observations indicate that PT-sensitive PLC regulation must employ an isoenzyme other than PLC- $\beta_{1}$. Hence, the available evidence indicates that at least two distinct PLCs are regulated by distinct $P T$-sensitive and -insensitive $G_{p}$ proteins.

This work was supported by Grant DK 25861 from the U.S. Public Health Service.

\section{REFERENCES}

1. Wahl, M. I., Nishibe, S. \& Carpenter, G. (1989) Cancer Cells 1, 101-107

2. Martin, T. F. J. (1991) Pharmacol. Ther. 49, 329-345

3. Taylor, C. W. \& Merritt, J. E. (1986) Trends Pharmacol. Sci. 7, 238-242

4. Cockcroft, S. (1987) Trends Biochem. Sci. 12, 75-78

5. Litosch, I. \& Fain, J. N. (1986) Life Sci. 39, 187-194

6. Lucas, D. O., Bajjalieh, S. M., Kowalchyk, J. A. \& Martin, T. F. J. (1985) Biochem. Biophys. Res. Commun. 132, 721-728

7. Martin, T. F. J., Bajjalieh, S. M., Lucas, D. O. \& Kowalchyk, J. A. (1986) J. Biol. Chem. 261, 10141-10149

8. Straub, R. E. \& Gershengorn, M. C. (1986) J. Biol. Chem. 261, 2712-2717
9. Aub, D. L., Frey, E. A., Sekura, R. D. \& Cote, T. E. (1986) J. Biol. Chem. 261, 9333-9340

10. Lo, W. W. Y. \& Hughes, J. (1987) FEBS Lett. 224, 1-3

11. Kikuchi, A., Kozawa, O., Kaibuchi, K., Katada, T., Ui, M. \& Takai, Y. (1986) J. Biol. Chem. 261, 11558-11562

12. Banno, Y., Nagao, S., Katada, T., Nagata, K., Ui, M. \& Nozawa, Y. (1987) Biochem. Biophys. Res. Commun. 146, 861-869

13. Polakis, P. G., Uhing, R. J. \& Synderman, R. (1988) J. Biol. Chem. 263, 4969-4976

14. Gierschik, P., Falloon, J., Milligan, G., Pines, M., Gallin, J. I. \& Spiegel, A. (1986) J. Biol. Chem. 261, 8058-8062

15. Moriarty, T. M., Padrell, E., Carty, D. J., Omri, G., Landau, E. M. \& Iyengar, R. (1990) Nature (London) 343, 79-82

16. Taylor, S. J., Smith, J. A. \& Exton, J. A. (1990) J. Biol. Chem. 265, $17150-17156$

17. Smrcka, A. V., Hepler, J. R., Brown, K. O. \& Sternweis, P. C. (1991) Science 251, 804-807

18. Gilman, A. G. (1987) Annu. Rev. Biochem. 56, 615-649

19. Rhee, S. G., Suh, P.-G., Ryu, S.-H. \& Lee, S. Y. (1989) Science 244, $546-550$

20. Banno, Y., Yada, Y. \& Nozawa, Y. (1988) J. Biol. Chem. 263, 11459-11465

21. Martin, T. F. J., Lucas, D. O., Bajjalieh, S. M. \& Kowalchyk, J. A. (1986) J. Biol. Chem. 261, 2918-2927

22. Martin, T. F. J. \& Kowalchyk, J. A. (1989) J. Biol. Chem. 264 20917-20922

23. Lee, K.-Y., Ryu, S. H., Suh, P.-G., Choi, W. C. \& Rhee, S. G. (1987) Proc. Natl. Acad. Sci. U.S.A. 84, 5540-5544

24. Harlow, E. \& Lane, D. (1988) Antibodies, A Laboratory Manual, p. 310, Cold Spring Harbor Laboratory, Cold Spring Harbor, NY

25. Martin, T. F. J., Hsieh, K.-P. \& Porter, B. W. (1990) J. Biol. Chem. 265, 7623-7631

26. Sternweis, P. C. \& Robishaw, J. D. (1984) J. Biol. Chem. 259, 13806-13813

27. Bokoch, G. M., Katada, T., Northup, J. K., Ui, M. \& Gilman, A. G. (1984) J. Biol. Chem. 259, 3560-3567

28. Offermanns, S., Schultz, G. \& Rosenthal, W. (1989) Eur. J. Biochem. 180, 283-287

29. Simonds, W. F., Goldsmith, P. K., Codina, J., Unson, C. G. \& Spiegel, A. M. (1989) Proc. Natl. Acad. Sci. U.S.A. 86, 7809-7813

30. Casey, P. J., Fong, H. K. W., Simon, M. I. \& Gilman, A. G. (1990) J. Biol. Chem. 265, 2383-2390

31. Matsuoka, M., Itoh, H., Kozasa, T. \& Kaziro, Y. (1988) Proc. Natl. Acad. Sci. U.S.A. 85, 5384-5388

32. Rock, C. O. \& Jackowski, S. (1987) J. Biol. Chem. 262, 5492-5498

33. Sommermeyer, H., Behl, B., Oberdisse, E. \& Resch, K. (1989) J. Biol. Chem. 264, 906-909

34. Bojanic, D., Wallace, M. A., Wojcikiewicz, R. J. H. \& Fain, J. N. (1987) Biochem. Biophys. Res. Commun. 147, 1088-1094

35. Claro, E., Wallace, M. A. \& Fain, J. N. (1990) Biochem. J. 268 733-737

36. Baldessare, J. J., Knipp, M. A., Henderson, P. A. \& Fisher, G. J. (1988) Biochem. Biophys. Res. Commun. 154, 351-357

37. Wang, P., Nishihata, J., Takabori, E., Yamamoto, K., Toyoshima, S. \& Osawa, T. (1989) J. Biochem. (Tokyo) 105, 461-466

38. Baldassare, J. J., Henderson, P. A. \& Fisher, G. J. (1989) Biochemistry 28, 6010-6016

39. Morris, A. J., Waldo, G. L., Downes, C. P. \& Harden, T. K. (1990) J. Biol. Chem. 265, 13508-13514

40. Litosch, I. (1989) Biochem. J. 261, 325-331

41. Claro, E., Wallace, M. A., Lee, H.-M. \& Fain, J. N. (1989) J. Biol. Chem. 264, 18288-18295

42. Carter, H. R., Wallace, M. A. \& Fain, J. N. (1990) Biochim. Biophys. Acta 1054, 119-128

43. Moriarty, T. M., Sealfon, S. C., Carty, D. J., Roberts, J. L., Iyengar, R. \& Landau, E. M. (1989) J. Biol. Chem. 264, 13524-13530

44. Boyer, J. L., Waldo, G. L., Evans, T., Northup, J. K., Downes, C. P. \& Harden, T. K. (1989) J. Biol. Chem. 264, 13917-13922

45. Strathmann, M. \& Simon, M. I. (1990) Proc. Natl. Acad. Sci. U.S.A. 87, 9113-9119

Received 27 March 1991/10 July 1991; accepted 17 July 1991 